\title{
Kernos
}

Revue internationale et pluridisciplinaire de religion grecque antique

$14 \mid 2001$

Varia

\section{The Cult of Aphrodite at Aphrodisias in Caria}

\section{Lisa R. Brody}

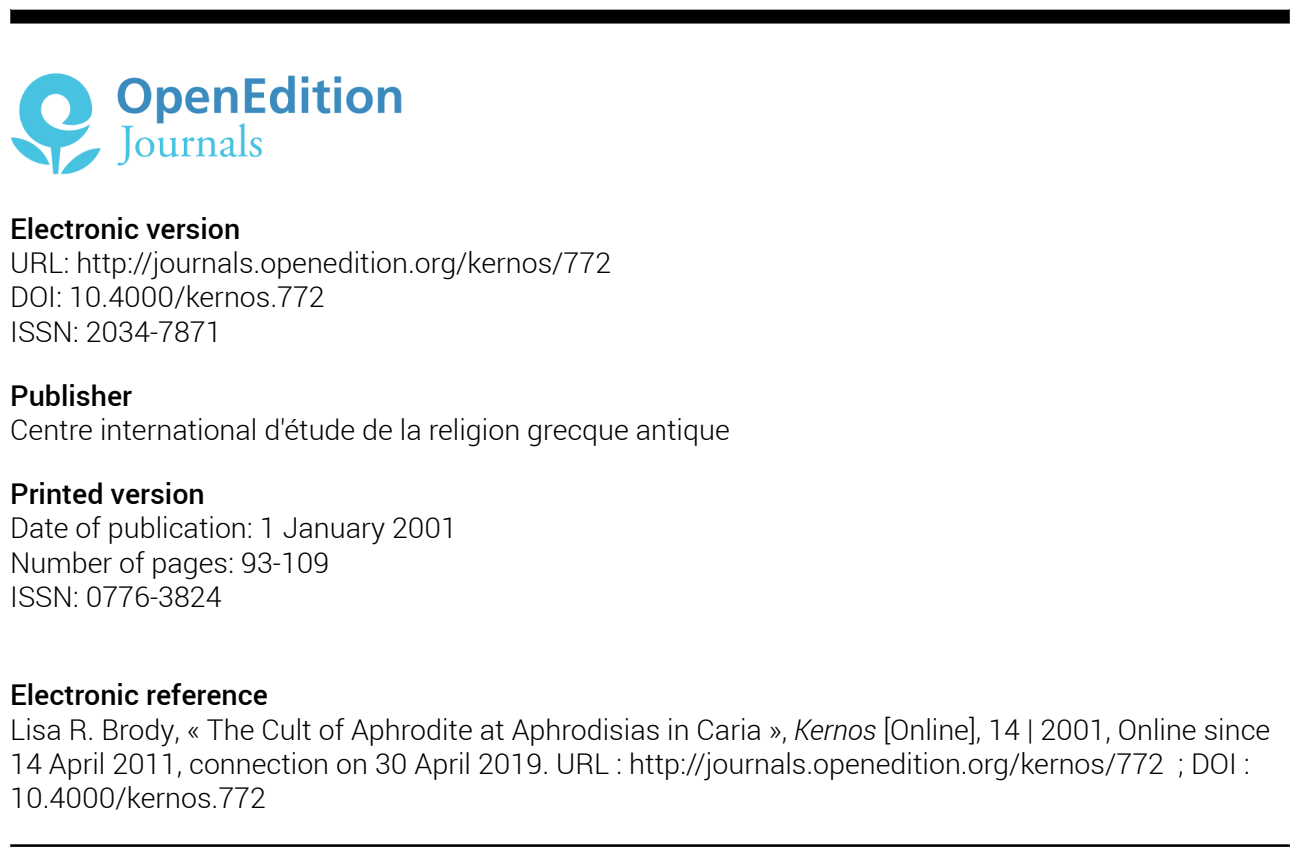

Kernos 


\section{The Cult of Aphrodite at Aphrodisias in Caria}

Graeco-Roman Asia Minor offers particular interest to scholars of ancient cult and religion, because many local Anatolian gods and goddesses at that time became identified with members of the Olympian pantheon, deities who had been introduced through increasing contact with mainland Greece and Italy. Although they came to be known by a variety of different names Artemis, Aphrodite, Zeus, Hera - the connection among these divinities is shown by specific similarities in their powers and attributes; many of them, for instance, had associations with fertility, warfare, vegetation, and animals. They probably originated as aspects of a universal, mother-type goddess, becoming identified in later periods with a variety of Greek and Roman counterparts. The Artemis of Ephesos, for instance, began as a local Ionian goddess called the Mistress, "Despina" in Greek, and it was in later periods that she became known as an unusual aspect of Artemis. Whereas Artemis seems to have been the most popular Greek deity in much of Asia Minor, particularly along the western coast, sanctuaries in other regions chose instead to identify their local goddesses as Kybele, Hera, or Aphrodite. Caria, in particular, seems to have preferred Aphrodite above all others. The bestdocumented case of this appears at Aphrodisias, a city whose very name from the Hellenistic period onward signifies the importance of its goddess's cult.

It is not surprising that the Great Goddess of Asia Minor was often associated with the Greek Aphrodite. Many scholars of Classical religion suppose that Aphrodite actually originated in the East, and even in antiquity writers such as Herodotos noted the similarities between Aphrodite and goddesses such as Astarte, Ishtar, and Inanna. Like the Aphrodisian goddess, these Mesopotamian deities represent fertility, love, and power in warfare. The Great Goddess in Anatolia is most often known as Kybele or Kubaba, and there are many similarities between Kybele and Aphrodite in myth. Both goddesses, for instance, have unfortunate relationships with mortal men: Attis and Adonis, respectively.

While the canonical image and iconography of the Aphrodite of A.phrodisias ure well known from a series of representations made in the Roman era, ${ }^{1}$ relatively little is known about the city's cult or its rituals. Most

1 L.R. Brody, Aphrodisias 2: The Image and Iconography of the Aphrodite of Aphrodisias, Mainz am Rhein, forthcoming. 
of the surviving evidence dates from the Roman period, leaving the early history and development of the cult shrouded in mystery. Even the original Carian name of the local goddess is unknown. Some speculation about the cult, however, is made possible through study of the sparse archaeological remains and comparison with other Carian sanctuaries.

The topographical center of the cult at Aphrodisias was the sanctuary of Aphrodite, located in the northern part of the city center. Much of this area was excavated between 1961 and 1986, and its architectural phases and chronology are relatively well understood. Early cult activity at Aphrodisias, which began at least by the Archaic period, may have pre-dated any monumental architecture. Neither an altar nor any other Archaic structures has yet been located archaeologically. The fact, however, that the Roman architecture in the sanctuary is not aligned with the Late Hellenistic street grid suggests that the orientation of the temple and temenos colonnades was probably dictated by some pre-existing sacred structure or shrine.

Early cult activity in the sanctuary is suggested by large quantities of excavated sherds dating to the Archaic period, as well as some architectural and sculptural fragments. The pottery fragments are primarily indicative of tableware shapes, and their overall high quality suggests a votive function. A fine three-nozzled lamp carved of green stone was also found near the temple and was dated by $\mathrm{J}$. de La Genière to the late seventh or early sixth century B.C., as were several Archaic terra-cotta figurines of seated females, probably representing goddesses.

Although little archaeological evidence from the Classical period has been found in the sanctuary of Aphrodite, aside from scattered potsherds, cult activity clearly continued during the fifth and fourth centuries B.C. At this point, however, it was still a small, local sanctuary, probably not attracting many visitors from outside the immediate vicinity. By the Hellenistic period, the increasing prosperity of the cult led to the association of the goddess with the Greek Aphrodite and to the creation of a new divine image. This image apparently demanded a more impressive architectural setting, and the first temple of Aphrodite was constructed.

The Hellenistic architectural evidence from the sanctuary includes a foundation wall that was excavated in 1965; it was recognized as being distinct from the later temple by its different orientation. Although there is little archaeological material to securely identify the purpose of this building, its location directly underneath the later temple suggests a cult function. Associated with this foundation is a floor mosaic of white, red, and dark blue rectilinear stone tesserae, for which a mid-third century B.C. terminus post quem is provided by several coins found beneath the mosaic. The building also seems to have had a faux marble wall décor; this is represented by small surviving pieces of painted plaster and stucco - wine red, deep yellow, black, and white - including part of a cornice with painted egg-and-dart and lotus- 
and-palmette decoration found in the surrounding Hellenistic strata. ${ }^{2}$ Small finds dating to the third and second centuries were also recovered during excavation of the temple area. Several terra-cotta figurines (including nude female goddess types, female heads, and a standing male youth - Attis?) further attest the continuation of cult activity in the sanctuary at Aphrodisias through the Hellenistic era. ${ }^{3}$

Most of the monumental architecture in the sanctuary of Aphrodite dates to the Roman Imperial period. Boundary stones marking the edges of the sacred precinct were erected by the wealthy freedman Zoilos; these read as follows:

[This area is] the sacred asylum [as defined by] the great [Caesar, the] dictator, and [his son] Imperator [Caesar and the] Senate and People of Rome, [as is also contained in the] grants of privilege, the public documents and decrees. C. Julius Zoilos, priest of Aphrodite, set up the [boundary stones. ${ }^{4}$

These markers were probably set up during the mid-30s B.C., after the senatus consultum de Apbrodisiensibus of 39 B.C. granted the privilege of asylia to the sanctuary. This decree is preserved in a copy of the second or third century A.D. on the parodos wall of the theater; its selection for this public "archive" shows that even centuries later it was still considered to be an important element of the religious self-identity of Aphrodisias. The relevant portion of the text says the following:

The temple or precinct of the goddess Aphrodite which is in the city of the Plarasans and Aphrodisians, that temple or precinct is to be an asylum, with the rights and religious sanctity which pertain to the temple of Ephesian Artemis at Ephesos, for an area of 120 feet surrounding the temple or precinct in all directions; that area is to be an asylum; and (it is agreed) that the community, and the citizens of Plarasa and Aphrodisias are to have, hold, use, and enjoy all those lands, places, buildings, villages, estates, strongpoints, pastures, and revenues which they had when they entered the friendship of the Roman people, and are to be free, and immune from taxation and the presence of tax-contractors. ${ }^{5}$

2 K. WELCH, The Temple of Apbrodite at Apbrodisias: a bistory of the building's excavation and a documentation of its Hellenistic phases, unpublished report.

3 Female figurines: Inv, 64-60, Inv, 64-62, Inv, 64-330; female heads: Inv. 63-63, Inv. 6464; male youth: Inv. 67-159.

4 R.R.R. SмIтH, Aphrodisias I: The Monument of C. Julius Zoilos, Mainz am Rhein, 1993, p. 12, T 5; J. ReYNolDs, Aphrodisias and Rome: documents from the excavation of the theater at Apbrodisias, London, 1982 (JRS Monograph, 1), Doc. 35; J. ReYNold, "Inscriptions and the Building of the Temple of Aphrodite", in C. Roveché, K.T. Erim (eds.), Apbrodisias Papers: Recent work on architecture and sculpture, Ann Arbor, 1990 (JRA Suppl. 1), p. 37. This text is reconstructed from two fragmentary stones.

5 ReYNolds, Aphrodisias and Rome (cit. n. 4), Doc. 8 (1. 55-61), with earlier references. 
The use of one hundred twenty feet as a demarcation for the Aphrodisian sanctuary seems to have been based on the unit of measurement used for the Late Hellenistic city grid. It was a common unit of measurement in Greek and Roman city planning, and is found in several places in Asia Minor, including Ephesos, Priene, and perhaps Miletos. ${ }^{6}$

The inviolability of the Aphrodisian sanctuary is also known from other epigraphic and literary sources. It is mentioned, for example, in Tacitus's account of embassies sent to Rome in A.D. 22 to defend the various rights and privileges of their sanctuaries:

Next the Aphrodisians and the Stratonikeans adduced a decree of the dictator Caesar in return for their earlier services to his cause, together with a modern rescript of the deified Augustus, who praised the unchanging fidelity to the Roman nation with which they had sustained the Parthian inroad. Aphrodisias, however, was championing the cult of Venus, Stratonikea that of Jove and Diana of the Crossways. ${ }^{7}$.

Although this text implies that a single decree granted asylum to both Aphrodisias and Stratonikea, it is possible that Tacitus has conflated the facts by saying "a decree" when in fact there were two. ${ }^{8}$ In any case, this evidence shows that it probably was Julius Caesar who first granted asylia to the sanctuary of Aphrodite; Augustus later confirmed it as a reward for the city's loyalty to Rome during the wars with Labienus Parthicus in $41 / 40$ B.C. The assumption that the privilege was instituted during the Imperial period, not earlier, is explained by K.J. Rigsby: "It was the temple [at Aphrodisias], not the city and country, that obtained asylia; this would be consistent with a grant originating under Roman rule and Roman thinking - an earlier recognition we might expect to be of the whole city and territory."

The freedman Zoilos, mentioned above, was also responsible for a new marble temple of Aphrodite that was constructed in the precinct during the 30 s or early 20 s, as shown by the inscribed door lintel: "C. Julius Zoilos, priest of Aphrodite, savior and benefactor of his homeland, (dedicated) the temple of Aphrodite." 10 This temple was a prestigious Ionic building, pseudodipteral in plan, surrounded by a peristyle of $8 \times 13$ columns. A continuous sculpted frieze above the columns featured garlands held by small figure figures wearing eastern clothing and "Phrygian" caps.

6 R.R.R. SMITH, C. RA'TTÉ, "Archaeological Research at Aphrodisias in Caria, 1995", AJA 101 (1997), p. 13.

7 TAC., Ann. III, 62 (Trans. Loeb). See SMith (cit. n. 4), p. 13, T 9.

8 I thank A. Chaniotis for this observation.

9 K.J. Rigsby, Asylia: Territorial Inviolability in the Hellenistic World, Berkeley, 1996, p. 428 .

10 ReYNolds, Aphrodisias and Rome (cit. n. 4), Doc. 37. 
Another major phase of building activity in the sanctuary of Aphrodite took place during the High Imperial era, when the temple was surrounded by an elaborate Corinthian temenos. Generally dated to the second century A.D. ${ }^{11}$ this enclosure consisted of stoas running along the north, west, and south sides of the temple. These stoas had monolithic, unfluted, grey marble columns topped with white marble capitals and entablature; a soffit band on the architrave was decorated with elaborate floral spirals. The eastern wall of the temenos had a complex aedicular façade on the side facing the temple, with niches crowned by alternating triangular and arched pediments containing relief shields and axes. ${ }^{12}$

Another alteration to the sanctuary, either contemporary with or slightly later than the temenos construction, included a monumental gateway on the far eastern edge of the sanctuary, standing along one of the city's major north-south avenues. This structure, the so-called "Tetrapylon," provided access into a large courtyard in front of the east façade of the temenos and was composed of four sets of four columns each. These columns employ a variety of different styles: the front columns of each set have spiral flutes, those in the second row are fluted vertically, and those in the last row are monolithic grey marble. All of the columns sit on high podium bases, and the entablature over the entrance contains an arcuated lintel. The relief decoration on the broken west pediment (the side facing the temple) contains small Erotes hunting in an elaborate landscape of acanthus foliage; the niche in the center once contained a bust of the Aphrodite of Aphrodisias. ${ }^{13}$

The final phase of construction in the sanctuary occurred when the temple was turned into a Christian basilica-church, probably in the late fifth century or early sixth century A.D. ${ }^{14}$ In the course of this conversion, the interior space was almost entirely razed, and a large amount of primary evidence about the early phases of the Aphrodisian cult was destroyed. The columns of the east and west sides were dismantled and used to extend the length of the north and south colonnades. The cella walls of the temple were removed and re-erected outside of the peristyle, so that the temple's lateral columns became the interior colonnades of the basilica's nave. The entrance of the building was shifted from east to west, and a semi-domed apse was

11 ReYNolds, Inscriptions (cit. n. 4), p. 40; S. Doruk, "The Architecture of the Temenos", in Aphrodisias Papers, p. 66-74.

12 Doruk (cit. n. 11), p. 69.

13 R.R.R. SMITH, "Archaeological Research at Aphrodisias, 1989-1992", in C. Roueché, R.R.R. SмiтH (eds.), Apbrodisias Papers 3: the setting and the quarries, mytbological and otber sculptural decoration, arcbitectural development, Portico of Tiberius and Tetrapylon, Ann Arbor, 1996 (JRA, Suppl. 19), p. 11. This bust was chiseled away in Late Antiquity and replaced with a Christian cross.

14 L. Hebert, The Temple-Church at Apbrodisias, Ph.D. diss, Institute of Fine Arts, New York University, 2000. 
built into the eastern end. Blocks from the temenos were used to create a narthex and a forecourt on the western end of the church, which remained in use until the Middle Byzantine period.

Aside from the temple itself, the architecture of the sanctuary remains somewhat enigmatic. Test excavations in the forecourt east of the temple have not revealed any major structures, suggesting that this area was primarily a large open space. There must have been an altar dedicated to Aphrodite, but it has not yet been discovered. A long dedicatory inscription from the Hadrianic period mentions some subsidiary buildings associated with the sanctuary, including a tbyepoleion deipnisterion (a hall for ritual banquets and sacrifices) and other oikemata, but these have not been identified archaeologically. ${ }^{15}$ This inscription further suggests that the banquet hall contained a statue of the local goddess, called an aphidryma. ${ }^{16}$ This word, used by ancient authors such as Strabo to mean a divine image, was restored in the passage by L. Robert. ${ }^{17}$ The term also appears with the same meaning in an inscription from Dura-Europos and is applied to statues of Asklepios in Athens and Dionysus at Magnesia on the Maeander. ${ }^{18}$

One important feature of the sanctuary of Aphrodite that was present from the beginning was a salt-water well. Pausanias mentions this well during his visit to the Athenian Acropolis, when he comments about the Erechtheion: "there is also inside - the building is double - sea-water in a cistern. This is no great marvel, for other inland regions have similar wells, in particular Aphrodisias in Caria." ${ }^{19}$ The existence of this well may in fact have been a major factor in the initial establishment of the cult at Aphrodisias, since water (particularly sea-water) had a strong significance for Aphrodite. Even before becoming known as Aphrodite, the Carian goddess probably also had a relationship to water, as did many other ancient Anatolian and Near Eastern goddesses. This connection may actually have been one inspiration for the identification of the Aphrodisian goddess with Aphrodite rather than with another Greek divinity.

Some features of the sanctuary that are attested for the Roman period may also have existed in the early phases of the Aphrodisian cult. Somewhere around the city was a stand of sacred trees belonging to Aphrodite. ${ }^{20}$ The

15 T. REINACH, "Inscriptions d'Aphrodisias", REG 19 (1906), \#138-41; L. ROBERT, La Carie: bistoire et géograpbie bistorique avec le recueil des inscriptions antiques, Paris, 1954 , p. 232-4, \#148; W.M. Calder, J.M.R. Cormack, Monuments from Lycaonia, the PisidioPbrygian Borderland, Aphrodisias, Manchester, 1962 (MAMA, VIII), \#413d, 1. 10.

16 Reinach (cit. n. 15), \#138-41; CALDER - CoRMACK (cit. n. 15), \#413e.

17 Strabo, IV, 179; VIII, 360, and XII, 537; L. RoberT, Hellenica. Recueil d'épigraphie, de numismatique, et d'antiquités grecques IV, Limoges, 1948, p. 119-125.

18 Dura-Europos: Prelim. Rep. V (1934) 112; Asklepios: IG $\mathrm{Il}^{2}$, \#1046; Dionysus: $I$. Magnesia, 215, 1. 5-7.

19 Paus., I, 26, 5.

20 REINACH (cit. n. 15), p. 107. 
presence of such a grove would be neither unusual nor surprising, since numerous sanctuaries of Aphrodite throughout the Mediterranean maintained gardens (including Knidos, Miletos, Cyrene, Corinth, Amathous, Patrai, and the sanctuary at the mouth of the Alpheios). "The sacred grove was a prominent feature in the ancient Greek religious landscape... One finds sacred groves in every part of the Greek mainland, on the Aegean islands and the shores of the Black Sea, in Asia Minor, Magna Graecia, Egypt, and the Near East - in short, in all parts of the Hellenic and Hellenized ancient world." ${ }^{21}$ Flowering plants and trees were associated with many goddesses, but particularly with Aphrodite, and a cultivated garden in the sanctuary at Aphrodisias would have emphasized the fertility aspect of the local goddess, possibly even before she came to be called Aphrodite.

The sanctuary at Aphrodisias also appears to have housed flocks of doves, which were considered to be sacred to the local goddess. The primary evidence for this comes from a fragmentary inscription on a marble base, dated to the second half of the first century A.D., found outside the city walls in $1934 .^{22}$ The text declares it forbidden to "catch, keep, or scare" the doves, which are somehow associated with the local goddess. Little else is known about the precise function of doves in the cult of Aphrodite. Two appear on the base of one of the surviving statuettes of the goddess, and the original temple statue could have stood on a similarly decorated base (although this is impossible to prove). Terra-cotta doves found in the sanctuary were probably votive dedications, and such offerings are common in sanctuaries throughout the Greek world. ${ }^{23}$ A dove perched on a budding branch also appears on an Aphrodisian coin type from the early third century A.D. ${ }^{24}$

The sanctity of doves was a long-established tradition in the Near East and Greece from the second millennium B.C. onward; they were associated with various Aegean fertility goddesses, including the Dea Syria, the Phoenician Astarte, and the Greek Aphrodite. As at Aphrodisias, doves were considered sacred in Babylonia because Queen Semiramis, wife of King Ninos and daughter of the goddess Derketo-Atargatis, was believed to have been transformed into a dove. ${ }^{25}$ This is particularly interesting for Aphrodisias, because Ninos and Semiramis were incorporated into the local

21 D.E. BIRGE, Sacred Groves in the Ancient World, Ph.D. diss., University of California, Berkeley, 1982, p. 16.

22 W.M. Calder, "Silius Italicus in Asia", $C R 49$ (1935), p. 216-217; A. Laumonier, Les cultes indigènes en Carie, Paris, 1958, p. 484; F. SoKolowsк, Lois sacrées de l'Asie mineure, Paris, 1955, p. 189-190; L. ROBERT, Hellenica XII. D'Aphrodisias à la Lycaonie, Limoges, 1965, p. 14; L. RoBert, "Les colombes d'Aphrodisias et d'Ascalon", JS (1971), p. $81 \mathrm{sq}$; M. Guarducci, "Anastasio e le colombe in un'epigrafe greca di Cirene", RendLinc 28 (1973), p. 587 sq.; ReYNolds, Apbrodisias and Rome (cit. n. 4), Doc. 46.

23 Inv. 64-268.

24 D. MacDonald, The Coinage of Aphrodisias, London, 1992, p. 120, Type 157.

25

Luc., De dea Syria, 14; Diod., II, 4, 4. 
foundation legends and depicted on a sculptured basilica frieze, along with an image of the Aphrodisian goddess. ${ }^{26}$ Other sanctuaries also considered doves to be sacred, as explained by R. MacMullen:

The whole city of Hierapolis [in Syria] served as sanctuary for doves held sacred to Atargatis. The effect can be judged from the scene at Ashkalon, in the same region. When Philo arrived there in his travels, he 'observed an enormous population of doves in the city squares and in every house. When I asked the explanation, I was told it was forbidden to catch them..., and the creatures, having no cause for fear, had become so domesticated that they not only regularly share one's roof but one's table too.' Similar consequences must be imagined at Aphrodisias, where the governor intervened to protect Aphrodite's holy doves; in Phrygia and Lydia, the gods themselves punished poachers. ${ }^{27}$

Since the iconography of the Aphrodite of Aphrodisias in the Hellenistic and Roman periods was so strongly influenced by mainland Greece, it is interesting to note the important role of the dove in Aphrodite's cult there. By the Classical period, the dove had become firmly established as a fundamental part of the goddess's iconography and ritual. The birds were sacrificed to Aphrodite Pandemos in Athens and in Delos, ${ }^{28}$ and votive terracotta doves are found in numerous sanctuaries to Aphrodite. ${ }^{29}$ Doves also appear on a frieze decorating the sanctuary of Aphrodite on the slopes of the Acropolis in Athens. ${ }^{30}$ Doves seem to have been particularly closely associated with the heavenly Aphrodite, Ourania. A bronze medallion from Pelinna, for instance, depicts this aspect of Aphrodite seated on a goat, surrounded by a kid, a ladder, and a dove. ${ }^{31}$ The protected status of doves at Aphrodisias therefore probably reflects the celestial aspect of the local goddess, one that was known to Greek-speakers as Aphrodite Ourania.

In addition to doves, the Aphrodite of Aphrodisias was also associated with lions, and this seems to pre-date her Hellenization, since it is a feature of goddesses at other early Anatolian cult sites as well. A marble lion's-head

26 See Brodx (cit. n. 1); B. YILDIRIm, The Ninos Reliefs from the Roman Civil Basilica of the South Agora at Apbrodisias in Caria, Ph.D. diss, Institute of Fine Arts, New York University, 2000.

27 R. MacMullen, Paganism in the Roman Empire, New Haven, 1981, p. 35; Philo Alex., De provid. II, c. 107. See also F. Cumont, Les religions orientales dans le paganisme romain: Conférences faites au Collège de France en 1905, Paris, 1929, p. 117. Ashkalon: Luc., De dea Syria, 54; Mount Eryx: AEl., Nat. Anim. IV, 2.

$28 I G \mathrm{II}^{2}, 659,23-5 ;$ S. MrLler, "Two Groups of Thessalian Gold", clst 18 (1979), p. 39 ก. 244.

29 V. Pirenne-Delforge, L'Aphrodite grecque. Contribution à l'étude de ses cultes et de sa personnalité dans le pantbéon archaique et classique, Liège, 1994 (Kernos, Suppl. 4), p. 415.

30 E. Simon, Die Götter der Griechen, Munich, 1969, p. 251-252, fig. 242.

31 Pirenne-Delforge (cit. n. 29), p. 416. 
water spout dating to the Archaic period was discovered in the Aphrodisian sanctuary in 1904 by French archaeologist Paul Gaudin. ${ }^{32}$ The precise function and original context of this fragment are uncertain. It may have belonged to some unidentified building in the sanctuary, or it may have been part of a fountain - perhaps one built over the sacred salt-water well. This is suggested by some Aphrodisian coins, which show the goddess standing beside a small object surmounted by a lion's head. ${ }^{33} \mathrm{~A}$ fountain with a spout in the form of a lion's head is depicted on the wall of an Etruscan tomb, circa 540 B.C. $;^{34}$ such fountains were common throughout the Mediterranean. Lions had connections to numerous Anatolian goddesses. Kybele, for example, is often depicted standing between two lions. These animals also appear in cult contexts at Sardis, where they obviously were considered sacred to the local goddess. ${ }^{35}$ It is therefore not surprising that lions were also important attributes for the Aphrodite of Aphrodisias. Fragments of several other Archaic stone lions were found around the sanctuary as well, ${ }^{36}$ and Texier saw a monumental sculpture of a lion reclining near the entrance to the precinct when he visited the site in $18355^{37}$

The Aphrodisian goddess was perhaps above all known as a goddess of warfare in her early phases of development, and this continued even after she became known as Aphrodite. It is in fact her enduring reputation as a military divinity that motivates Sulla to make his dedication at the sanctuary in the early first century B.C. ${ }^{38} \mathrm{He}$ chooses for his offering a golden double axe, a weapon that has powerful meaning for a number of Carian deities; it is often the attribute of Zeus, as with Zeus Labraundos. The double axe appears frequently on Aphrodisian coins. In the beginning, it was probably associated not with the local goddess, but with a god called Zeus Nineudios. This name, Nineudios, is a toponym that confirms the local character of the

32 Izmir Museum \#331 (later returned to the Aphrodisias Museum). M. Coll.ignon, "Note sur les fouilles exécutées à Aphrodisias par M. Paul Gaudin", CRAI (1904), p. 706; K.T. ErIM, "De Aphrodisiade", AJA 71 (1967), p. 240, pl. 66; K.T. ERIM, Apbrodisias, City of Venus Apbrodite, New York/London, 1986, p. 58; J. DE LA GENIÈrE, "Premières recherches sur Aphrodisias préromaine", in K.T. ERIM, J. DE LA GENIÈre (eds.), Aphrodisias de Carie. Colloque du Centre de recherches arcbéologiques de l'Université de Lille III, 13 novembre 1985, Paris, 1987, p. 54, fig. 60; J. DE LA Genière, “À propos d'une monnaie de Tibère : lions et fontaines dans le sanctuaire", in Apbrodisias Papers, p. 44, fig. 8.

33 DE LA GeNière (cit. n. 32), fig. 1.

34 G.Q. Giglioli, L'arte etrusca, Milan, 1935, p. 22, pl. 107; A. RumpF, Malerei und Zeucbnung der klassiscben Antike, Munich, 1953, p. 55, pl. 15.2; G.M.A. Hanfmann, From Croesus to Constantine: the cities of Western Asia Minor and their arts in Greek and Roman times, Ann Arbor, 1975, p. 14, fig. 33

35 HANFMANN (cit. n. 34), p. 14.

36 DE La Genière (cit. n. 32), figs. 10-13.

37 C. Texinr, Asie Mineure: description géographique, bistorique et archéologique, Paris, 1862, p. 645.

38 App., $B C, \mathbf{I} .97$. 
god and signifies "Zeus of (the place called) Ninoë." Stephanus of Byzantium asserts that Aphrodisias was originally known as Ninoë. ${ }^{39}$

Although little specific information is known about the cult of Zeus at Aphrodisias, it was clearly an important one. The early coinage of Aphrodisias attests the significance of this god. Along with the double axe, images on the coins include a cuirass, probably representing military strength, an eagle, and a bearded male god. It appears that in early periods, the cult of the Aphrodisian goddesses was somewhat eclipsed by that of Zeus. One of the earliest known historical documents from the site, an oath signifying the alliance of Plarasa/Aphrodisias with Cibyra and Tabae, probably dating from the second century B.C., is dedicated not to Aphrodisias but to Zeus (though called Zeus Philios, not Nineudios), Homonoia, and Dea Roma. ${ }^{40}$ By the late Hellenistic period, however, the local goddess had become associated with Aphrodite and her cult so increased in importance that she became the city's primary divinity and the inspiration for its new name, Aphrodisias.

The coexistence at Aphrodisias of a goddess cult and a cult of Zeus is paralleled at many other sites in Asia Minor. By the late Hellenistic period in Sardis, for instance, Artemis shared a precinct with Zeus Polieus. ${ }^{41}$ Another such combination appeared at Magnesia on the Maeander, where a version of Zeus known as Zeus Sosipolis was worshipped along with the primary local goddess, Artemis Leukopbryene. These two cults at Magnesia were closely connected; the temple of Zeus adjoined the temple dedicated to Artemis, and the priestess of Artemis participated regularly in the festival of Zeus. ${ }^{42}$ Since no separate sanctuary of Zeus has yet been identified at Aphrodisias, it is likely that there, too, both divinities were worshipped in a single precinct. The close relationship between the local god and local goddess at Aphrodisias is further shown by Sulla's choice of a double axe for his dedication to Aphrodite, since this weapon was traditionally a symbol of the Carian Zeus.

Some information about the cult personnel of the Aphrodisian goddess in the Roman period is provided by epigraphic and sculptural evidence. Since the cult was of such central importance to the city, Aphrodite's clergy and administrators received accordingly high status, and the offices were filled by prominent Aphrodisian citizens. Some of the positions (biereus, neopoios) were common to many Greek and Anatolian sanctuaries, while others (antbepboros, archineopoios) were rare and may have been virtually unique to Aphrodisias. The overall organization of the cult also seems to have been

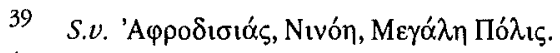

40 Reynolds, Apbrodisias and Rome (cit, n. 4), Doc. 1.

41 C. Ratté, T.N. Howe, C. Foss, "An Early Imperial Pseudodipteral Temple at Sardis", AJA 90 (1986), p. 45 n. 1, with earlier references.

42 J. FeRguson, The Religions of the Roman Empire, London, 1970, p. 37.
} 
relatively simple in comparison to other contemporary cults, such as that at Ephesos, which incorporated a much larger number of cult officials.

The Aphrodisian cult was directed by a priest (biereus), who held the office for life. ${ }^{43}$ Numerous prominent citizens of Aphrodisias served as priests of Aphrodite, including Gaius Julius Zoilos and Dometeinos Diogenes. ${ }^{44}$ Some scholars have maintained that Aphrodisias had a college of priests headed by a high priest (archiereus), but this assertion stems from an incorrect restoration of archiereus in the dedicatory inscription of the Hadrianic Baths. In fact, the title archiereus is always used at Aphrodisias in reference to priests of the Imperial cult, not of Aphrodite. ${ }^{45}$

Statues of priests of Aphrodite were erected prominently around the civic center of Aphrodisias. An over-life-size portrait of Dometeinos, for example, stood in front of one of the primary doors to the Bouleuterion, inside the north stoa of the North Agora. His status as biereus is clearly shown by his priestly crown, which bears a bust of the local goddess. Dometeinos also served as a priest of the Imperial cult, as indicated by the fact that his crown also features busts of Roman emperors and their wives. Another priest of Aphrodite, probably from the fourth century A.D., appears as a headless bust found in a large, elaborate domestic building known as the "Atrium House." This man, whose name is unknown, can be identified as a priest of Aphrodite because he holds a statuette of the local goddess in the crook of his left arm. Erim hypothesized "a connection with religious, semi-religious, or official activities" in the building because two small marble altars, decorated with garlands, were excavated there as well. ${ }^{47}$

In addition to the priest of Aphrodite, the local cult was also served by a group of priestesses known as antbephoroi, "flower-bearers." ${ }^{48}$ It is not at all surprising to find that flowers were involved in the cult rituals at Aphrodisias. The precise role that these priestesses performed is uncertain, although their title probably refers to something that they carried in a procession. Laumonier cautioned that anthephoros might refer only to the costume worn by the priestesses, possibly cloth embroidered with floral designs, citing the kbrysopboroi at Magnesia and at Ephesos as parallels. ${ }^{49}$ Anthephoros, however, more likely refers to something that the priestesses carried, as with

\footnotetext{
43 SMITH (cit. n. 4), p. 12, T 6.

44 Zoilos: ReINACH (cit. n. 15), \#54; Other priests: CAlder - CoRMACK (cit. n. 15), \#450, \#478; SEG 26.1219 and 1220; SEG 31.900; REYNOLDS, Apbrodisias and Rome (cit. n. 4), p. 55.

45 L. Robert, “Inscriptions d'Aphrodisias", AC 35 (1966), p. 414.

46 BRoDy (cit. n. 1), \#14; K.T. ERIM, "Recent Work at Aphrodisias 1986-1988", in Aphrodisias Papers, p. 15-18, fig. 9.

47 ERIM (cit. n. 46), p. 15.

48 Calder - Cormack (cit, n. 15), \#514, \#516;SEG, 40.926; CIG, 2782, 2778, 2821-2;

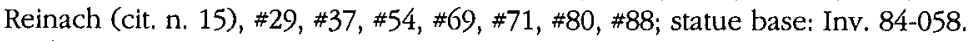

49 LAUMONIER (cit. n. 22), p. 484.
} 
the kosmopboroi at Ephesos and the kleidopboroi at Lagina and at Claros. The title antbephoros is known elsewhere only in the cult of Kore and Demeter on Thasos. ${ }^{50}$

The Aphrodite of Aphrodisias was also served by an official called a neokoros; this title is known primarily from inscriptions on Aphrodisian coins. ${ }^{51}$ It also, however, appears on a statue base found in the Baths of Hadrian, where the city honors a man who is identified as "neokoros of the goddess Aphrodite." ${ }^{2}$ Reynolds dates this base by its letter forms to the late second or early third century A.D., although she notes that the names listed would seem to place it in the earlier second century. The numismatic evidence, all of which is from the Severan period, supports the later date. Since no mention of this title survives from the Early Imperial period, it is possible that the office of neokoros was a late development in the organization of Aphrodite's cult.

The administration of the cult was also supervised by a group of neopoioi, who were responsible for the successful management of the cult and the sanctuary, particularly in regard to financial matters. The same title is found at several other Anatolian and Greek sanctuaries, including Ephesos, Sardis, Priene, Teos, Miletus, Magnesia on the Meander, Iasos, Halikarnassos, Samos, Paros, Amorgos, Delphi, and Athens. ${ }^{53}$ "This was a board which handled moneys belonging to Aphrodite and took responsibility for maintenance and new construction within the precinct, and, in some circumstances (it seems) outside it too." 54 They also supervised the payment of fines to the sanctuary of Aphrodite as penalties for various civic violations. ${ }^{55}$ The title of these officials is generally given as neopoios, but some later inscriptions include an additional honorific, kbrysopboros. ${ }^{56}$ This term probably refers to their role as guardians of some golden object or objects belonging to the goddess, as at Ephesos. ${ }^{57}$ The group had a chairman, who is referred to either as arcbineopoios or protoneopoios. ${ }^{58}$ This particular office may have been unique to Aphrodisias, as it does not appear at any of the other sanctuaries where there were neopoioi. The date of the initial

50 IG XII 8, 526, cf. 609.

51 MacDonald (cit. n. 24), p. $35 s q$, mentions the numismatic evidence but not the corroborative epigraphic sources.

52 L. Robert, Études anatoliennes, Amsterdam, 1970, p. 299 n. 2; ReYnolds, Apbrodisias and Rome (cit. n. 4), p. 168.

53 C. PICARD, Éphèse et Claros. Recherches sur les sanctuaries et les cultes de l'Ionie du nord, Paris, 1922, p. 98 n. 6.

54 ReYNolds, Inscriptions (cit. n. 4), p. 39.

55 CIG 2826.

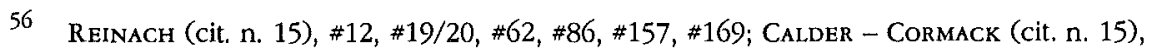
$\# 499, \# 501, \# 506, \# 520, \# 523, \# 525, \# 555, \# 579, \# 593$.

57 PiCARd (cit. n. 53), p. 242-3.

58 ReINACH (cit. n. 15), \#71, \#77, \#85, \#146bis; CALDER - CormaCk (cit. n. 15), \#410, \#513. 
organization of the Aphrodisian neopoioi is uncertain, but Reynolds suggests that it occurred in the Early Imperial period, perhaps in order to assist with details of construction and finance for the marble temple of Aphrodite. A text originally inscribed on the cella wall lists names of several men, who Reynolds believes "may have been donors, but more probably priests, or perhaps members of the board of neopoioi."

The cult of Aphrodite also included regular festivals, but little information survives about them. Certain festivals are known to have been supervised by the neopoioi and by the priest of Aphrodite. For example, the role played by these officials in organizing the games known as the Callicrateia are laid out in a letter to the city composed by a Roman curator in the $180 \mathrm{~s}$ A.D. ${ }^{60}$ This assignment seems to have been a consequence of the high civic status of the neopotoi, not necessarily an indication that the Callicrateian games were associated with the cult of Aphrodite. There were other Aphrodisian festivals, however, some of which probably were connected with the cult of Aphrodite. Some candidates include the Apbrodiseia Pbilemoneia, held every four years, and the Apbrodiseia Adoneia. ${ }^{61}$ These designations may in fact refer to a single major cult festival, simply called the Apbrodiseia, with the different modifiers reflecting its changing patrons. ${ }^{62}$

One festival that does seem to have been cult-related is the Apbrodiseia Isolympia, attested in an inscription from Rhodes. ${ }^{63}$ It appears on a stele recording the victories of a Rhodian runner at a series of contests called

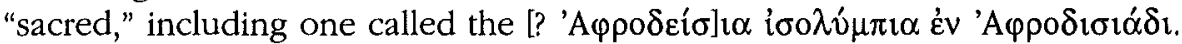
The restoration of the name Apbrodiseia here is suggested by another passage in the same text that mentions a victory in the 'A

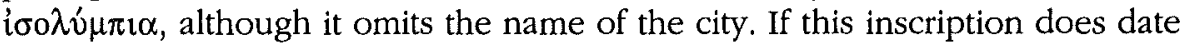
to the first century A.D., as suggested by Carratelli, it is by far the earliest reference to an athletic contest at Aphrodisias. ${ }^{64}$ The construction of the stadium at Aphrodisias probably also dates to the early or mid-first century A.D. and may therefore be associated with the initiation of this festival and the augmentation of the cult of Aphrodite during the Early Imperial period. No references to the Apbrodiseia Isolympia have been securely identified at Aphrodisias itself, although it has been suggested that the "City Contest" ( $\pi \mathrm{o} \lambda \varepsilon \imath \tau \kappa o ̀ \varsigma \alpha \dot{\alpha} \omega$ v) mentioned in an inscription of the early 180 s could refer to the same festival. ${ }^{65}$

\footnotetext{
59 REYNOLDS, Inscriptions (cit. n. 4), p. 39.

60 C. Roueché, Apbrodisias in Late Antiquity: the Late Roman and Byzantine Inscriptions, London, 1993 (JRS Monograph, 5), \#51 (A.D. 180-189, probably early 180s).

61 Laumonier (cit. n. 22), p. 485.

62 I thank A. Chaniotis for this suggestion.

63 Roueché (cit. n. 60), p. 163.

64 ROUECHÉ (cit. n. 60), p. 163.

65 K. WELCH, "The Stadium at Aphrodisias", AJA 101 (1997), p. 359.
} 
Votive offerings dedicated to the Aphrodite of Aphrodisias were, for the most part, typical of dedications throughout the Greek world. One of the most historically significant offerings to the goddess is the one made by L. Cornelius Sulla in 89 or 88 B.C.; this is also the earliest securely dated evidence of any kind concerning the Aphrodisian cult. Appian gives the following account of this dedication:

I have discovered a document which tells that Sulla was named Epaphroditus by a decree of the Senate itself; this does not appear to me to be inappropriate, since he was also called Faustus, and this name seems to have almost the same significance as Epaphroditus. And somewhere an oracle was also given to him which said these things concerning his future:

Believe me, Roman! Kypris gives great power

And cares for the line of Aeneas. You must bring yearly gifts

To all the Immortals; do not neglect this;

And especially to Delphi. But there is a place where

snow-covered Taurus climbs up, where there is a high

Carian city, its inhabitants named after Aphrodite,

Take a double axe there, and you will have vast power!

Whichever inscription the Romans decreed when they erected the statue, they seem to me to have inscribed it either to mock the man or to please him. However, Sulla did actually send a golden crown and axe, inscribed with these words:

This was dedicated to Aphrodite by the dictator Sulla, For he saw her in a dream, taking charge at the head of his army forming men of war, and fighting in full armor. ${ }^{66}$

The section in this story about the oracle may not be authentic. Appian is quite vague about it, not even specifying the location of the oracle, and the epigram accompanying the dedication does not even mention it. Instead, Sulla declares that his gift was motivated by Aphrodite's appearance in his dream. His own words emphasize the martial aspect of the Aphrodisian goddess, and he presents his offerings to her in hope of future military victories. The deity's power in battle derives from her original, local identity and explains Sulla's choice of an axe for his offering, the double axe being an ancient Carian symbol.

Another famous Roman who sent a dedication to the Aphrodite of Aphrodisias was Julius Caesar. This gift is described in a letter written by Octavian to the people of Ephesos in 39/38 B.C.:

I was also informed that out of the loot a golden Eros, which had been dedicated by my father to Aphrodite, has been brought to you and set up as an offering to Artemis.

66 App., BC, 1.97 (Trans. Chaniotis). The reference to "snow-covered Taurus" is probably an erroneous conflation of the Carian Aphrodisias with another Aphrodisias in Rough Cilicia. 
You will do well and worthily of yourselves if you restore the offering which my father gave to Aphrodite. In any case, Eros is not a suitable offering when given to Artemis.

For concerning the Aphrodisians, upon whom I have conferred such great benefits, it is necessary that I should take the care about which I think you too have heard. ${ }^{67}$

A golden figure of Eros would have been a highly appropriate offering for Aphrodite, of course, at Aphrodisias or anywhere in the Mediterranean world.

The most common types of votive dedications included marble or bronze statues, representing any of several subjects: mythological figures (Graces, Seasons, gods, Erotes), portraits of victorious athletes, personifications, animals, etc. ${ }^{68}$ These images were erected not only in the sanctuary of Aphrodite but all around the city. Many of their inscribed bases have been excavated at Aphrodisias, but their precise original settings are often unknown, due to the fact that most of them were reused in Late Antiquity and therefore are found in secondary contexts.

The wealthiest petitioners would offer votive objects made of precious materials to the Aphrodite of Aphrodisias; again, this is true for divinities throughout the ancient world. Examples already mentioned for Aphrodisias include the golden dedications from Sulla and Caesar, but others are attested as well. For instance, an honorific inscription from the theater, dated to the second century A.D., records that "the Council and the People (honored) G. Hosidius Julianus, a lover of his country and a benefactor, who dedicated money for contests [on a ?-year] cycle and to the goddess Aphrodite bequeathed (offerings) of silver inlaid with gold as set out in his will." ${ }^{69}$ Another fragmentary inscription describes a golden priestly crown ( $\tau$ òv

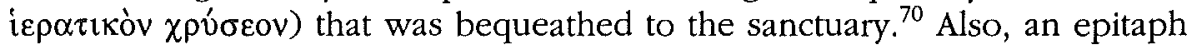
on a sarcophagus mentions the provision of regular donations to the sanctuary of Aphrodite to finance some sort of "golden decoration," perhaps meaning adornments for the temple statue itself. ${ }^{71}$

In addition to statues and small objects, there were several buildings around the city of Aphrodisias that were dedicated to Aphrodite, always in

67 ReYNolds, Apbrodisias and Rome (cit. n. 4), Doc. 12.

68 Graces: CALDER - Cormack (cit. n. 15), \#416; CIG 2756; RoBERT, Hellenica (cit. n. 22), p. 116-9; Seasons: Reinach (cit. n. 15), \#19/20; Hermes, Aphrodite, and Erotes: Calder - Cormack (cit. n. 15), \#448; Robert, Hellenica (cit. n. 22), p. 118; Demos: SEG 41.921; other statues: Reynolds, Apbrodisias and Rome (cit. n. 4), Doc. 55.

69 Roueché (cit. n. 60), p. 176, Doc. 55b.

70 CIG, 2782. An example of such a crown was found in a sanctuary of Isis and Serapis at Douch in Egypt (ancient Kysis). See M. REDDÉ, "Le Trésor de Douch", CRAI (1989), p. 427-45, esp. fig. 3.

71 I thank A. Chaniotis for this information. 
conjunction with either the Demos, the Patris, or the Imperial family. The stage building of the theater, for example; is dedicated with the following inscription: "Gaius Julius Zoilos, freedman of the divine Julius's son Caesar, after being stephanephoros for the tenth time in succession (dedicated) the stage and the proskenion with all the ornaments on it, to Aphrodite and the Demos." ${ }^{72}$ Other sections of the theater, including later revisions and additions, were also dedicated to the goddess. ${ }^{73}$

The Aphrodite of Aphrodisias not only received dedications but, in some cases, was actually responsible for financing monuments and dedicating them to the city or to the Roman emperor. These projects, such as the elaborate Hadrian bath complex, were completed with funds from the sanctuary, which were considered part of the civic treasury. ${ }^{74}$ Another text mentions certain andriantotbekai ("places for statues") that were dedicated by Aphrodite herself, meaning that these were probably also financed with temple funds. ${ }^{75}$ Further indications that the temple and city treasuries were at least partially identical are provided by inscriptions that require various penalties and reparations to be paid to the goddess as punishment for civic crimes. ${ }^{76}$ Also, several sarcophagi found at Aphrodisias charge violators of the grave to pay a fine to the sanctuary of Aphrodite; this type of penalty was common in the Greek and Roman worlds. ${ }^{77}$

\section{Conclusion}

Beginning around the seventh century B.C., Aphrodisias in Caria became known as the center of worship for an important local goddess. Because its archaeological preservation is better than that of most other sites in Caria, this ancient city provides modern scholars with a useful example of a typical Carian cult center, particularly in the Hellenistic and Roman periods. Like other goddesses worshipped in Caria, the Hellenization and urbanization of the region caused the local deity at Aphrodisias also to become Hellenized and associated with the Greek Aphrodite. Most of the evidence about the goddess and her cult post-dates this transition, which probably occurred around the second century B.C. Little is known, therefore, about the origins

72 Smith (cit. n. 4), p. 11, T 2; ReYNolds, Apbrodisias and Rome (cit. n. 4), Doc. 36.

73 J. Reynolds, "Epigraphic evidence for the construction of the theatre: $1^{\text {st }}$ c. B.C. to mid $3^{\text {rd }}$ c. A.D.", in R.R.R. S SITH, K.T. ERIM (eds.), Aphrodisias Papers 2: the theatre, a sculptor's worksbop, pbilosopbers, and coin-types, Ann Arbor, 1991 (IRA Suppl., 2), p. 2228.

74 A. Boulanger, "Note sur les fouilles exécutées à Aphrodisias en 1913", CRAI (1914), p. 49 n. 2; Laumonier (cit. n. 22), p 483.

75 TEXIER (cit, n. 37), p. 161-2; CIG 2749.

76 E.g. Calder - Cormack (cit. n. 15), \#547, \#567, \#573; Reinach (cit. n. 15), \#163.

77 E.g. Calder - Cormack (cit. n. 15), \#555, \#565, \#571, \#576, \#577, \#579, \#593, \#594, \#494; C. Rounché, Performers and Partisans at Apbrodisias in the Roman and Late Roman Periods, London, 1993 (JRS Monograph, 6), p. 193-194, Doc. 148. 
and early development of the Aphrodisian divinity, not even her original Carian name.

Some of the features of the Aphrodisian sanctuary and cult rituals that are attested for the Roman era probably did develop at an earlier date. Unfortunately, the lack of primary evidence from the pre-Hellenistic periods makes it difficult to identify precisely when these various features originated. The fact that the canonical image of the Aphrodite of Aphrodisias involves Anatolian and Greek iconographic elements, but none with specifically Roman significance, suggests that the statue was created before the Imperial period. The cult, likewise, seems to have been developed by the Hellenistic period, since its organization was typical of Greek, rather than Roman, cults. By analyzing the archaeological remains from this well-preserved Carian sanctuary, and by comparing them with material from other cult sites in Caria and elsewhere in Anatolia, it is possible to approach a clearer understanding of the strong local religious traditions in western Asia Minor and their persistence through the Hellenistic and Roman eras.

Oregon State University

Lisa R. Brody

Department of Art and Art History

Corvallis, OR 97331 